\title{
O PROBLEMA DO MAL NA OBRA ORIGENS DO TOTALITARISMO, DE HANNAH
}

\section{ARENDT}

\section{THE PROBLEM OF EVIL IN WORK THE ORIGINS OF TOTALITARIANISM OF HANNAH ARENDT}

\section{Gutierrez de Lellis Resende*}

Algumas correntes da filosofia moderna, entre elas o Iluminismo e o Positivismo, anunciaram que a razão elevaria a humanidade a patamares de evolução nunca antes alcançados, chegando-se a um estágio em que todos os males seriam superados, e o homem se tornaria, enfim, autossuficente. O século $\mathrm{XX}$, entretanto, trouxe aos homens inúmeras catástrofes - dentre elas, as terríveis guerras mundiais - causadas e potencializadas, entre outros motivos, pela própria razão. A filosofia desenvolvida nesse século foi fortemente marcada por acontecimentos inimagináveis que mostraram que o mal pode tomar proporções alarmantes. Sendo assim, é preciso repensá-lo e, também, outros inúmeros conceitos e ideias filosóficas que ruíram com tais eventos. Uma das grandes defensoras dessa tese é Hannah Arendt (1906-1975), que percebeu o surgimento de uma ruptura na cultura ocidental e, a partir disso, propôs novas formas de pensar e fazer política.

Na concepção da filósofa, essa ruptura - hiato entre passado e futuro - dá-se com o totalitarismo. Essa experiência política, vivida na Alemanha de Hitler e na Rússia de Stalin, mostrou ser um divisor de águas na história da humanidade, pois os regimes totalitários demonstraram ser uma nova forma de governo e de domínio, pondo "[...] em questão os critérios políticos e tradicionais de avaliação da atividade política, demonstrando o esgarçamento de nossa tradição do pensamento político para propor-lhe antídotos eficazes" (DUARTE, 2000, p. 25). Pela primeira vez, vemos um governo que pretende e consegue dominar o homem totalmente, tanto em sua vida pública quanto em sua vida privada. Entre muitas tragédias, o assassinato em massa de pessoas sem nenhum critério utilitário desafia nosso entendimento e capacidade de compreender os fatos.

Depois de ter vivido na pele a experiência totalitária germânica, o totalitarismo será o pano de fundo de todo o pensamento filosófico e político arendtiano. Seus pensamentos, seus

\footnotetext{
* Graduado em Filosofia pela PUC Minas (2015).
} 
conceitos, suas reflexões, suas obras giram em torno desse tema; são uma tentativa de responder as questões explanadas no parágrafo anterior. As reflexões de Hannah Arendt como sobre a liberdade, a importância do pensamento, os direitos humanos, o poder do povo - surgem como antíteses à destruição causada pela ruptura totalitária.

A primeira grande obra da autora, Origens do totalitarismo (1951), é uma análise dessa “[...] forma inédita de governo apoiada na ideologia, na burocracia e no terror e caracterizada pela ubiquidade do medo" (LAFER, 1988, p. 76). Na forma original, o livro é divido em três partes: "Antissemitismo", "Imperialismo" e "Totalitarismo".

As duas primeiras partes têm o objetivo de analisar os elementos que se cristalizaram na dominação totalitária, que é devidamente analisada na terceira parte da obra. Antissemitismo e imperialismo trouxeram uma prefiguração do que seria mesmo o fenômeno totalitário, mas não o causaram de forma mecânica. Ambos não foram causas que, necessariamente, teriam de chegar ao governo totalitário. Há na realidade "[...] uma relação de convergências, convergência de acontecimentos que culmina por cristalizar-se em totalitarismo, e convergência de conceitos que esclarecem esta convenção" (SOUKI, 1998, p. 48).

Antissemitismo e imperialismo compartilham com o totalitarismo o aspecto de novidade. $\mathrm{O}$ antissemitismo moderno não é mais aquele preconceito religioso que existiu na Idade Média. É, porém, um movimento laico surgido da identificação do judeu com o Estado; sendo assim, os judeus catalisaram os ressentimentos da sociedade civil em relação ao Estado. Já o imperialismo é visto como a inversão de ideais na qual a economia passa a ter prioridade sobre a política, e isso se caracteriza principalmente pela expansão econômica a qualquer custo. O antissemitismo moderno antecipará o conceito de inimigo objetivo usado pelo totalitarismo, enquanto o imperialismo, as ideias de expansão, racismo e burocracia, que resultarão numa noção de superfluidade dos seres humanos.

Mas nossa atenção se dirige de maneira especial à terceira parte da obra, "Totalitarismo", em que são delineados os principais pontos que caracterizam essa forma de governo. Na tentativa arendtiana de compreender o funcionamento dos regimes totalitários, Arendt percebe uma nova modalidade do mal, compreendido em âmbito político, através da noção de mal radical. Se essa expressão do mal foi percebida primeiramente no totalitarismo, é preciso compreender, antes, o que foi esse regime.

Quando se busca compreender o totalitarismo, a primeira característica que nos salta aos olhos é o seu estatuto de novidade. A originalidade desse sistema político é tão grande, 
que ele foi capaz de solapar todas as categorias do pensamento político até então vigentes. Não existem paralelos com outras formas de governo anteriores, sejam elas a tirania, a ditadura, o despotismo, o absolutismo etc. É o primeiro governo a visar ao domínio total do homem.

Por essa razão, nossa filósofa nos adverte: “[...] o domínio total é a única forma de governo com o qual não é possível coexistir. Assim, temos todos os motivos para usar a palavra 'totalitarismo' com cautela" (ARENDT, 2012, p. 420). Portanto, Arendt faz questão de delimitar o totalitarismo a uma forma de governo do século XX, presente na Rússia de Stalin entre 1930 e 1953 - com suspensão no período da segunda guerra mundial - e na Alemanha de Hitler a partir de 1938 até o término da guerra. ${ }^{1}$ Entretanto, ela não exclui a possibilidade de um retorno do totalitarismo: “[...] a crise de nosso tempo e a sua principal experiência deram origem a uma forma inteiramente nova de governo, que, como potencialidade e como risco sempre presente, tende a ficar conosco de agora em diante" (ARENDT, 2012, p. 639). As características relevantes sobre esse sistema de governo serão apontadas a seguir, principalmente no seu aspecto de inovação e ruptura.

A primeira característica do totalitarismo demonstrada pela autora é que ele se baseia no apoio amplo e irrestrito das massas, que são um conglomerado de pessoas oriundas de todas as classes da sociedade cuja única característica em comum é, justamente, a falta de um interesse comum. Vemos aí um aspecto de ruptura: enquanto as classes sociais se articulam em torno de algum interesse em comum, as massas não o fazem; elas “[...] constituem a maioria das pessoas neutras e politicamente indiferentes" (ARENDT, 2012, p. 439). Sendo assim, quebra-se o paradigma da democracia, que não consegue representar toda a população, como é pretendido, já que as massas não conseguem formular interesses a serem representados.

O homem de massa surge em consequência da atomização da sociedade, é um indivíduo isolado, que não se relaciona socialmente e está desenraizado. É ele, e não o comunista convicto ou nazista fanático, o súdito perfeito para o regime totalitário, ao contrário

\footnotetext{
${ }^{1} \mathrm{O}$ fato de Arendt enquadrar no mesmo tipo de governo duas formas antagônicas de se governar - uma capitalista, outra socialista - foi motivo para muitas discussões. Entretanto, nossa filósofa vê, de forma plausível, pontos em comum nos governos de Stalin e de Hitler. Mas é preciso reconhecer que Arendt acaba priorizando o a análise do regime nazista em detrimento de algo mais aprofundado sobre o regime stalinista, principalmente no que se refere aos elementos que antecederam o totalitarismo. Isso ocorreu devido às experiências pessoais de Hannah Arendt, que, por ser de origem alemã, sofreu os males do totalitarismo germânico e, também, pelo motivo de o livro ser publicado em tempos nos quais o regime comunista soviético se mantinha ainda de pé, dificultando acesso a documentos. Como a autora, enquadraremos nosso texto no caso nazista.
} 
do que se poderia pensar. Isso se dá porque, em sua inabilidade política e falta de lugar no mundo, o homem de massa encontra apoio, coerência e sentido na ideologia totalitária.

Arendt denomina a organização de indivíduos que aspira ao totalitarismo, antes de chegar ao poder, de movimento totalitário. Para conquistar as massas, o movimento utiliza a propaganda, pois necessita de "[...] parecer plausível aos olhos de um público que ainda não está rigorosamente isolado de todas as outras fontes de informação" (ARENDT, 2012, p. 474). A propaganda se dirige, portanto, aos segmentos não totalitários da nação, ao mundo externo; é usada quando o terror não pode ser usado, e perde sua função num Estado já tomado pelo totalitarismo. Usando teorias conspiratórias e dando coerência aos fatos, a propaganda consegue ludibriar as massas, criando um “[...] mundo fictício capaz de competir com o mundo real, cuja principal desvantagem é não ser lógico, coerente e organizado" (SOUKI, 1998, p. 67). Além disso, a propaganda não se contenta apenas com a mentira, mas é capaz de torná-la uma verdade, o que mostra o ineditismo desse tipo de propaganda em relação à propaganda política normal, a uma simples demagogia.

Quando se assume o poder e ocorre a eliminação de todos os oponentes ao regime, a propaganda não é mais necessária. Agora o domínio das massas será baseado na doutrinação pela ideologia e na presença constante do terror, que serão os dois pilares de um governo totalitário.

Ideologia, para Arendt, é a lógica de uma ideia, tendo como objeto a história. O nazismo usará a ideia do racismo, e o stalinismo usará o comunismo. Mas a centralidade da ideologia totalitária não está na ideia, mas no processo lógico que se desdobra a partir da ideia. Tanto que Hitler e Stalin serão considerados ótimos ideólogos, mesmo sem terem inventado o racismo ou o comunismo. Eles foram mestres, na verdade, em aplicar essa ideia como lei absoluta e fazer com que tudo se desdobre dela. O processo histórico que se extrai dessa lei é importantíssimo e se sobrepõe a tudo e todos: há uma primazia do movimento. Sendo assim, faz sentido matar milhões de judeus já que se está adiantando um serviço da história, que é a evolução contínua dos seres humanos até se chegar à vitória de uma raça superior. Essa lei da qual tudo é deduzido é usada, consequentemente, para explicar e dar coerência lógica ao mundo, respondendo aos anseios da massa por coerência, lógica e sentido. A ideologia explica tudo sem o menor compromisso com a realidade. Há uma ruptura do senso comum, o que equivale à perda do espaço comum público, perda da mediação entre o sujeito e os outros, já que o diálogo é desnecessário: tudo, inclusive o pensamento, é reduzido à mera dedução lógica. 
Com a ideologia, é empregado concomitantemente o terror. Verdadeira essência do regime totalitário, o terror visa a exterminar com a espontaneidade e a imprevisibilidade, características próprias do ser humano. Extinguindo-se a liberdade humana, que é sua capacidade de começar, o homem fica estabilizado e, com isso, é possível liberar as forças da lei da natureza (nazismo) ou da história (stalinismo), acelerando os processos por elas iniciados. Pode-se dizer, portanto, que o terror é a realização da lei do movimento. Diante do terror e da lei, os perseguidos pelo governo não serão necessariamente os opositores do regime - até porque já estão todos eliminados nessa fase -, mas sim pessoas totalmente inocentes aos olhos do mundo não totalitário. Os culpados são, simplesmente, aqueles que atrapalham o caminho da lei da natureza ou da história; esses são os inimigos objetivos que deverão ser exterminados. O objetivo de eliminar totalmente a espontaneidade humana, o terror como essência do governo e a escolha arbitrária dos perseguidos são características que revelam, mais uma vez, o caráter inédito do totalitarismo.

Pela arbitrariedade da escolha das vítimas, há uma igualdade dos indivíduos perante o terror, já que qualquer um pode ser considerado um inimigo. Essa igualdade é instrumentalizada pela ação da polícia secreta, verdadeiro ramo executivo do governo, e que demonstra o real objetivo totalitário: a dominação total. O Estado é somente uma fachada para o mundo não totalitário, pois o núcleo do poder está com a polícia secreta. Ela está totalmente sujeita ao líder, sendo responsável por executar suas normas no que se refere ao extermínio da população, diferentemente dos serviços secretos de outros tipos de governo, cuja função é descobrir crimes.

A existência simultânea de um Estado de fachada e de um verdadeiro núcleo de governo, a polícia secreta, demonstra a característica peculiar de organização totalitária, totalmente nova e já presente desde a época do movimento, baseada na multiplicação de funções que garantem uma filtragem da realidade. Lafer (1988, p. 95-96) resume o modelo de organização totalitária segundo a percepção arendtiana nas seguintes palavras:

[...] a imagem mais adequada para a sociedade, o Estado e o Direito nos regimes totalitários não é a da tradicional pirâmide, mas sim a de uma cebola. No centro, numa espécie de vazio, localiza-se o líder. Tudo o que ele faz, ele o faz de dentro, não de fora ou de cima. Todas as múltiplas contraditórias instâncias do Estado e da sociedade totalitária, por sua vez, relacionam-se de tal modo que cada uma delas é fachada numa direção e centro na outra. Quanto mais próximo do centro da cebola, maior é o segredo e o poder. 
A burocracia totalitária permite uma filtragem da realidade e, portanto, uma dominação mais eficaz das massas, que não entendem o funcionamento do sistema. E como o totalitarismo não suporta nenhuma forma de estabilização, porque necessita que tudo esteja em constante movimento, ocorrerá sempre uma transferência dos centros de poder.

Todos esses elementos totalitários encontrarão sua máxima expressão nos campos de concentração e extermínio, único local onde se verificou a dominação total do homem. Por isso, eles são vistos como o laboratório do totalitarismo, instituição central do poder totalitário por mostrar que o ser humano pode ser inteiramente dominado. Para que isso ocorra, mais do que exterminar os homens, o objetivo central dos campos de concentração é exterminar a natureza humana, ou seja, transformar o homem em coisa, eliminando qualquer forma de espontaneidade e liberdade. Nas palavras de nossa filósofa, “o domínio total, que procura sistematizar a infinita pluralidade e diferenciação dos seres humanos como se toda a humanidade fosse um só indivíduo, só é possível quando toda e qualquer pessoa seja reduzida à mesma identidade de reações" (ARENDT, 2012, p. 582).

Como locais cujo objetivo é pura e simplesmente a transformação da natureza humana, vê-se que os campos de extermínio desafiam o nosso pensamento. Mesmo assim, Hannah Arendt se propõe a compreendê-los. "Se é verdade que os campos de concentração são a instituição que caracteriza mais especificamente o governo totalitário, então deter-se nos horrores que eles representam é indispensável para compreender o totalitarismo." (ARENDT, 2012, p. 586).

Para entender o funcionamento dos campos de concentração, nossa filósofa, primeiramente, condenará o uso de paralelos para explicá-los, porque os horrores cometidos dentro dos campos são inimagináveis, e se situam fora da vida e da morte, pois produzem seres humanos que, na verdade, são "mortos-vivos", e, por isso, invalidam qualquer analogia. “Assim, todo paralelo cria confusão e desvia a atenção do que é essencial. O trabalho forçado nas prisões e colônias penais, o banimento, a escravidão, todos parecem, por um instante, oferecer possibilidade de comparação, mas, num exame mais cuidadoso, não levam a parte alguma." (ARENDT, 2012, p. 589). Nesses ambientes, as pessoas possuem valor definido (nem que seja comercial), ainda são consideradas seres humanos, e nem há domínio total. Já no campo de concentração, os que lá estão não detêm nenhuma dessas garantias, os internos são inteiramente supérfluos, parecem nem mesmo existir.

A impossibilidade de comparação se mostra ainda mais clara quando notamos o fato de que os campos de concentração não possuíam qualquer valor utilitário. Não rendia 
qualquer lucro do ponto de vista econômico ao estado totalitário. O trabalho realizado nesses espaços poderia produzir muito mais frutos em menos tempo e poderia ser realizado de forma mais barata em outras condições. Mesmo em tempos de guerra, em que, tradicionalmente, a economia de um país gira em torno dos combates, a Alemanha gastou um enorme montante na construção e manutenção de campos de extermínio, como Auschwitz. Todos esses fatores demonstram a real intenção totalitária, "[...] denunciam a verdadeira destinação dos campos de concentração: a de não servirem para coisa alguma, senão para a destruição da liberdade; e a de não gerarem produto final algum, a não ser uma pilha de cadáveres" (DUARTE, 2000, p. $68)$.

Ante uma aparência de completa loucura e irrealidade, as melhores imagens que Hannah Arendt encontrou para descrever tais lugares, ainda que com algumas limitações, foram as da escatologia católica. Considerando que existem três tipos diferentes de campos, ela usou as imagens de Limbo, Purgatório e Inferno para explicar o funcionamento de cada um desses tipos de campos. Segundo as palavras de Arendt (2012, p. 591):

\begin{abstract}
Ao Limbo correspondem aquelas formas relativamente benignas, que já foram populares mesmo em países não totalitários, destinadas a afastar da sociedade todo tipo de elementos indesejáveis - os refugiados, os apátridas, os marginais e os desempregados -; os campos de pessoas deslocadas, por exemplo, que continuaram a existir mesmo depois da guerra, nada mais são do que campos para os que se tornaram supérfluos e importunos. O Purgatório é representado pelos campos de trabalho da União Soviética, onde o abandono alia-se ao trabalho forçado e desordenado. O Inferno, no sentido mais literal, é representado por aquele tipo de campo que os nazistas aperfeiçoaram e onde toda a vida era organizada, completa e sistematicamente, de modo a causar o maior tormento possível.
\end{abstract}

Recorrer a metáforas religiosas talvez seja a saída necessária diante de uma realidade em que descrições tradicionais são insuficientes. Um lugar em que o mal chega a proporções alarmantes e inesperadas só pode ser comparado ao inferno. Entretanto, a analogia é falha quando percebemos que, na visão tradicional cristã, há critérios claros e discerníveis para definir aqueles que serão condenados à danação eterna. Conforme já ressaltado, no sistema totalitário, o castigo pode ser destinado a qualquer um, já que a escolha dos internos dos campos se dá sem nenhum critério discernível.

A aleatoriedade na escolha dos internos dos campos de concentração se juntou com outros fatores, que serão esclarecidos abaixo. Juntos, eles contribuíram para um sistema de fabricação de "cadáveres vivos". Nas sucursais do inferno, a morte física do homem foi precedida pela morte da pessoa jurídica, da pessoa moral e da espontaneidade humanas. 
Segundo Hannah Arendt, esse processo, uma das maiores crueldades totalitárias, mostrou uma expressão radical do mal.

A primeira etapa desse processo, a destruição da pessoa jurídica do homem se dá “"[...] com a perda de todos os direitos civis na privação de nacionalidade, bem com a criação de um sistema de punição no qual esta independe da conduta" (DUARTE, 2000, p. 69). A desnacionalização em massa ocorrida após a Primeira Guerra Mundial fez com que milhares de pessoas se tornassem inexistentes perante a lei de qualquer país; tais pessoas foram privadas de ter direitos, deixaram de existir juridicamente. A destruição jurídica se aprofundou no sistema "concentracionário", no qual a maioria dos internos nada fizera para que lá estivesse. Esta é uma característica essencial dos campos: a imensa maioria das vítimas são pessoas inocentes, não pagava por um crime cometido, estava ali, simplesmente, porque fora enquadrada de modo arbitrário dentro do conceito de inimigo objetivo. Os inimigos objetivos eram determinados não porque ofereciam um risco real ao Estado, mas eram tidos como um grupo de pessoas com certas tendências que poderiam atrapalhar o movimento das leis da história ou da natureza. O grupo de pessoas que se enquadra nesse conceito é mudado de tempos em tempos, de acordo com a conjuntura do momento. Esse sistema aleatório tem como objetivo final destruir os direitos civis da população, possibilitando a onipresença do medo e permitir, no fim, a dominação total. É o que Celso Lafer (1988, p. 109-110) nos diz:

\footnotetext{
os internados dos campos de concentração do tipo inferno, na sua esmagadora maioria, nada tinha feito que tivesse uma ligação racional com o fato de terem sido presos, nem em sua consciência, nem na consciência de seus atormentadores. Eram inocentes em todos os sentidos e, por isso, prestavam-se perfeitamente, enquanto grupo, à experiência radical da privação absoluta de direitos e da total destruição da personalidade jurídica.
}

O segundo passo no processo de dominação total do ser humano pretendido pelo totalitarismo consistiu na morte da pessoa moral do homem. Isso se obteve pelo anonimato dado à própria morte. Não existem mais mártires ou heróis, a solidariedade humana e a resistência foram exterminadas. Após morto, o indivíduo cai em completo esquecimento, deixa de existir: "a morte apenas selava o fato de que ele jamais havia existido" (ARENDT, 2012, p. 600). A moral é invertida. O mandamento deixou de ser "não matarás" e passou a dizer "matarás". Os próprios internos eram colocados para trabalhar no processo de extermínios, sendo forçados a agir como assassinos. Não há mais limite entre vítima e assassino, detento e carrasco. O totalitarismo torna todos os homens iguais. 
Por fim, matou-se a individualidade e, portanto, a espontaneidade do homem. Consegue-se fazê-lo por meio de tentativas de manipulação do corpo humano a fim de destruir os vestígios de singularidade: condições precárias de transporte para os campos, uniformização, raspagem dos cabelos, métodos de tortura, entre outras. A destruição fria e sistemática dos corpos de homens inteiramente normais se dava por homens também normais, treinados para serem algozes que atingiam a perfeição. A morte da individualidade acarre ta a destruição da espontaneidade, "[...] a capacidade do homem de iniciar algo de novo com os seus próprios recursos [...]. Morta a individualidade, nada resta senão horríveis marionetes com rostos de homem, [...] todas reagindo com perfeita previsibilidade mesmo quando marcham para a morte" (ARENDT, 2012, p. 603).

Sabendo-se que a individualidade e a espontaneidade são sérios obstáculos ao totalitarismo, pois a imprevisibilidade impede o domínio total do ser humano, entendemos por que os campos de concentração são a instituição central do governo totalitário. Nessas fábricas de morte, é criado o súdito perfeito para o sistema totalitário: o homem totalmente supérfluo. "O totalitarismo não procura o domínio despótico dos homens, mas sim um sistema em que os homens sejam supérfluos." (ARENDT, 2012, p. 605). O sistema "concentracionário" reduz o homem a um feixe de reações, transforma sua natureza, transformando-o em um animal, em coisa.

Segundo as percepções arendtianas, os campos de concentração do totalitarismo são verdadeiras fábricas da superfluidade humana, revelando-se pela primeira vez uma expressão radical do mal. A convicção totalitária diz que tudo é possível; mas, na verdade, demonstrou que tudo pode ser destruído, inclusive a natureza humana.

Sendo assim, a deformação da natureza do homem é o grande mal totalitário, maior que todos os outros horrores causados por essa forma de governo. Segundo Arendt, quando se fala na fabricação da superfluidade nos campos de concentração e extermínio, "a questão não está no sofrimento, do qual sempre houve demasiado na terra, nem no número de vítimas. $\mathrm{O}$ que está em jogo é a natureza humana em si [...]” (ARENDT, 2012, p. 608). Até então, somente essa forma de governo foi capaz de demonstrar tamanha perversidade. De agora em diante, devemos esforçarmo-nos ao máximo para que o domínio total não aconteça novamente, "pois a vitória dos campos de concentração significaria a mesma inexorável ruína para todos os seres humanos que o uso militar da bomba de hidrogênio traria para toda a raça humana" (ARENDT, 2012, p. 589). 
Para abarcar as dimensões inéditas que o mal tomou no totalitarismo, Arendt passou a concebê-lo como radical: “e, se é verdade que, nos estágios finais do totalitarismo, surge um mal absoluto (absoluto, porque já não pode ser atribuído a motivos humanamente compreensíveis), também é verdade que, sem ele, poderíamos nunca ter conhecido a natureza realmente radical do Mal” (ARENDT, 2012, p. 13). Tal concepção havia sigo ignorada pela filosofia até o momento em que a autora escreveu Origens do totalitarismo. Isso se deu porque só agora nos deparamos com um desejo de destruir a natureza humana que conseguiu cumprir a sua vontade.

A partir do ocorrido, não é possível nem o perdão nem o crime: “[...] em seu afã de provar que tudo é possível, os regimes totalitários descobriram, sem o saber, que existem crimes que os homens não podem punir nem perdoar" (ARENDT, 2012, p. 608). O mal totalitário é impunível porque não há como enquadrar os crimes totalitários dentro da tradição jurídica. É, também, imperdoável porque, além de não se poder perdoar o assassínio em massa, o totalitarismo foi capaz de destruir os limites entre assassino e vítima. Qual pena seria justa para os homens que organizaram a morte de milhares de maneira impessoal e fria, para pessoas que queriam degenerar a natureza do ser humano? Como falar de perdão e punição se as próprias vítimas, em alguns casos, auxiliaram na mortandade dos seus companheiros? "Do mesmo modo como as vítimas nas fábricas da morte ou nos poços de esquecimento já não são 'humanas' aos olhos de seus carrascos, também essa novíssima espécie de criminosos situa-se além da própria solidariedade do pecado humano.” (ARENDT, 2012, p. 609). Estamos diante de uma perversidade que conseguiu fazer com que toda a população dos países totalitários ou a sua imensa maioria - tornasse aceitável o sistema "concentracionário". Encontramo-nos perante uma forma de mal que não encontra fundamentação em motivos compreensíveis. Não se pode enquadrá-lo como uma forma de inveja, ressentimento, desejo de poder etc.

Sendo assim, essa nova forma de mal proporcionada pelo regime totalitário não pode ser abordada dentro de um modelo ético e moral, como havia sido trabalhada até aquela época. A solução será recorrer a um viés político, tentando, assim, compreender o inexplicável e refletir sobre uma forma de governo que, pela primeira vez na história, baseouse no extermínio de homens e de sua natureza. Por isso, Arendt introduz as noções de mal radical e mal absoluto, que resultarão num tratamento desse assunto numa perspectiva política. Segundo André Duarte (2000, p. 73): 
Com estas noções Arendt sintetizou os traços paradoxais da ruptura instituída pelos atos empreendidos pelos regimes totalitários, os quais exigem ser compreendidos justamente porque põem em questão as convicções, os conceitos políticos e os padrões do julgamento moral a partir dos quais a tradição ocidental compreendeu os limites entre o "possível e o "impossível" no mundo [...].

A noção introduzida por Arendt é inovadora e, portanto, choca-se com tudo aquilo que a tradição havia nos legado sobre o fenômeno do mal. Vemos, com certo ineditismo, uma espécie de mal praticado não por motivações malignas. Grandes reflexões e tratados desenvolvidos sobre o tema, presentes nos escritos filosóficos de Platão, Agostinho, Tomás de Aquino, Leibniz e outros, não conseguem abarcar o mal totalitário. A concepção da teologia cristã também não ajudou muito na compreensão de tal tema. Sobre o aspecto inovador dessa nova abordagem do mal, Arendt (2012, p. 609) diz:

\begin{abstract}
É inerente a toda a nossa tradição filosófica que não possamos conceber um "mal radical", e isso se aplica tanto à teologia cristã, que concebeu ao próprio Diabo uma origem celestial, como a Kant, o único filósofo que, pela denominação que lhe deu, ao menos deve ter suspeitado de que esse mal existia, embora logo o racionalizasse no conceito de "rancor pervertido" que podia ser explicado por motivos compreensíveis. Assim, não temos onde buscar apoio para compreender um fenômeno que, não obstante, nos confronta com sua realidade avassaladora e rompe com todos os parâmetros que conhecemos.
\end{abstract}

Sendo assim, nem mesmo Kant, o filósofo que, para Hannah Arendt, mais perto chegou da concepção de mal radical, conseguiu conceber um mal que não possa ser explicado por motivos compreensíveis.

Segundo Correia e Souki, Kant desenvolverá sua doutrina sobre o mal radical em $A$ religião dentro dos limites da simples razão (1793). A tentativa kantiana nessa obra será a de situar as doutrinas da religião dentro de suas teorias filosóficas, desenvolvidas, principalmente, nas suas três grandes críticas. Portanto, ele pretende sujeitar a fé à razão. Em A religião dentro dos limites da simples razão, tudo girará em torno do mal radical. Segundo Kant, o homem é capaz de se desviar da lei moral, mesmo tendo consciência dela. Ao dizer isso, ele admite que o homem possui uma propensão para o mal. Entretanto, mesmo que tenha raízes na natureza humana, o mal possui limites. "O supremo fundamento subjetivo da liberdade está corrompido, mas essa corrupção não é malignidade, não é mal pelo mal, mas sim 'perversão' do coração [...]”' (SOUKI, 1998, p. 29). Mesmo tendo uma propensão maligna, existe em cada homem, antes de tudo isso, uma disposição originária para o bem.

A concepção arendtiana de mal radical ultrapassa a ideia kantiana sobre o mesmo assunto. Se Kant encontra algum motivo compreensível para explicar a origem desse mal, 
Hannah Arendt dirá que ele não é explicável. Se aquele diz que o mal tem limites, esta dirá que é ilimitado, absoluto. É por isso que o adjetivo "radical" tem significação diferente para os filósofos. Kant o usa no sentido de arraigado, com raízes. Já Arendt o emprega no sentido de absoluto, de extremo. Segundo Correia (2013, p. 70), "na medida em que identifica mal radical com mal absoluto ou extremo, Hannah Arendt se distancia da compreensão kantiana do mal radical como uma propensão a inverter a ordem das motivações que estaria na raiz de todo mal moral e seria universal".

A compreensão de mal radical como mal absoluto trará alguns problemas para Hannah Arendt. $\mathrm{O}$ adjetivo absoluto pode conferir a essa forma extrema de se fazer o mal características de invencibilidade e indestrutibilidade. Pode-se, ainda, atribuir caráter substancial a um fenômeno extremamente frágil e passageiro. Em vista disso, surgem algumas críticas à concepção arendtiana de mal radical. A própria autora de Origens do totalitarismo reconhecerá, em escritos posteriores, que o uso do termo radical foi um pouco equivocado. Numa carta dirigida a Gerhard Scholem, citada por Lafer (1988, p. 179), Arendt dirá que o mal totalitário não pode ser radical, porque é isento de profundidade e de dimensão demoníaca.

O abandono do termo mal radical se dará de forma definitiva através de uma nova percepção acerca do mal proporcionado pelos regimes totalitários desenvolvida em Eichmann em Jerusalém: um relato sobre a banalidade do mal (1963). Ao saber que Adolf Eichmann havia sido capturado pelo estado israelita e que, em breve, seria levado a julgamento, Hannah Arendt se oferece como repórter para uma revista norte-americana a fim de cobrir aquele que seria o maior julgamento de um oficial nazista após o tribunal de Nuremberg. O réu era responsável pela organização do transporte de prisioneiros para os campos de concentração. Pensando que iria se deparar com um dos mais inteligentes e perversos nazistas, ela se depara com um homem medíocre, extremamente superficial, incapaz de elaborar reflexões.

Embora praticasse atos monstruosos, Eichmann não era um monstro e, muito menos, um demônio. Mesmo conduzindo milhões de judeus aos campos de extermínio, contribuindo, assim, diretamente para a morte deles, ele era um ótimo pai de família e um "exemplar" cidadão alemão, ciente de seus direitos e deveres. Fez o que fez por autêntica inabilidade de pensar. A falta de uma reflexão crítica e a incapacidade de pensar desse oficial nazista levaram-no e, talvez, a tantos outros, a cometer crimes de tamanhas proporções.

O mal praticado por Eichmann ao mostrar-se sem profundidade, sem aspecto demoníaco, mas capaz de se espalhar na superfície da terra como um fungo o faz, revela-se 
banal. E a partir da figura vazia do réu em julgamento, Arendt introduz a noção de banalidade do mal, abandonando de vez a concepção de mal radical:

\begin{abstract}
A imagem de Eichmann como uma figura comum, e mesmo banal, a pensar por clichês, do qual não se pode extrair qualquer profundidade diabólica, fez com que Hannah Arendt mudasse de ideia e deixasse de utilizar o termo "mal radical", que na sua compreensão poderia sugerir uma profundidade ou uma radicalidade que de fato os perpetradores desses crimes não possuíam necessariamente. (CORREIA, 2013, p. 72).
\end{abstract}

Apesar de Arendt preferir abandonar uma abordagem radical do mal em vista de um novo termo, é preciso dizer que as ideias acerca do mal apresentadas pela autora em Origens do totalitarismo e em Eichmann em Jerusalém não se contrapõem. Pelo contrário, complementam-se. Ambas as noções "[...] têm a mesma base comum de experiências, sintetizando os paradoxos instituídos pelos regimes totalitários [...]" (DUARTE, 2000, p. 72).

Seja banal, seja radical, o mal totalitário é sempre um desafio a nossa compreensão. É quase impossível entender sua motivação. Portanto, para entendê-lo é preciso analisar as consequências que por ele foram originadas. Ao abordar o mal de um ponto de vista político, em uma nova roupagem, o interesse estará em suas implicações. "Para Arendt, o mal político não se deixa compreender plenamente em termos das suas possíveis motivações, cabendo apenas analisar as suas terríveis consequências para o mundo.” (DUARTE, 2000, p. 72).

A partir do que já foi dito anteriormente, fica claro que o grande produto totalitário é a superfluidade humana. Segundo Arendt (2012, p. 609), “apenas uma coisa parece discernível: podemos dizer que esse mal radical surgiu em relação a um sistema no qual todos os homens se tornaram igualmente supérfluos". No sistema totalitário, os homens perdem todo o seu valor e passam a ser considerados como coisas, perdendo aquilo que os torna estritamente humanos; por isso são descartáveis, controláveis e supérfluos. Cada passo que se dá na implantação do domínio total é um passo que se dá na transformação da natureza humana, produzindo superfluidade nos indivíduos.

A ligação intrínseca entre totalitarismo e superfluidade humana pode ser notada no fato de que os regimes totalitários só se desenvolveram em países cujo número de habitantes era consideravelmente grande. Uma das características notáveis do sistema totalitário é a dizimação de boa parte da população e, portanto, países com índices populacionais baixos não têm estrutura suficiente para receber um governo de tal tipo. A partir disso, vemos que governos totalitários europeus só puderam se tornar possibilidade a partir do fim do século XIX, em regiões onde percebemos elementos que permitiram a cristalização de um domínio 
total: crescimento populacional, quebra do sistema de classes e o surgimento duma sociedade de massas, aumento do número de desempregados, entre outros. O totalitarismo só se torna viável em locais onde existem grandes massas supérfluas, que podem ser eliminadas sem, necessariamente, resultar em um país despovoado.

A ação totalitária de tornar todos os homens supérfluos - seja pela escolha aleatória daqueles que irão para os campos de concentração, seja pela liquidação em massa de pessoas, seja pela expulsão constante do aparelho do governo - é apenas reflexo da sensação de superfluidade que as massas modernas já apresentavam desde o começo da Revolução Industrial. As pessoas passaram a se sentir sem lugar no mundo. $\mathrm{O}$ homem de massa é um indivíduo totalmente isolado e atomizado, não possui contato com os outros, não participa das relações sociais comuns, não possui raízes. Desse modo, o desarraigamento foi condição preliminar para a existência da superfluidade, que é quando os seres humanos já não pertencem ao mundo de forma alguma.

O total afastamento do mundo dá-se nos campos de concentração através do domínio total do homem. As vítimas desses laboratórios do terror perderam toda a sua singularidade e espontaneidade. Antes mesmo da morte física, os internos dos campos se comportam como "mortos-vivos", acabam se tornando meros fantoches na mão dos agentes da polícia secreta. As pessoas vítimas do domínio total são exemplo da forma mais extrema de superfluidade em seres humanos já conhecida. Seres supérfluos são os súditos perfeitos para o governo totalitário, pois “[...] o poder total só pode ser conseguido e conservado num mundo de reflexos condicionados, de marionetes sem o mais leve traço de espontaneidade" (ARENDT, 2012, p. 605).

Se uma expressão radical do mal só foi possível graças à capacidade totalitária de tornar homens supérfluos e, em nossos tempos, vemos essa capacidade ainda presente, é preciso lutar contra tais elementos que conspiram para o domínio total do homem. A queda dos governos de Hitler e Stalin não significa necessariamente a queda de todos os elementos totalitários, como nos aponta Arendt (2012, p. 639) nas páginas finais de Origens do totalitarismo: "[...] a crise de nosso tempo e a sua principal experiência deram origem a uma forma inteiramente nova de governo que, como potencialidade e como risco sempre presente, tende infelizmente a ficar conosco de agora em diante [...]".

Entre os elementos totalitários que vemos em nossos governos ainda hoje, mesmo os que se dizem democráticos, podemos citar: a estrutura burocrática, a manipulação de massas por parte da imprensa e Estados que são capazes de investigar a fundo a vida de seus 
cidadãos. A superfluidade das massas também resistiu à Segunda Guerra, e soluções totalitárias podem ser tomadas para resolver esse problema. Nas palavras de Arendt (2012, p. 609):

\begin{abstract}
O perigo das fábricas de cadáveres e dos poços de esquecimento é que hoje, com o aumento universal das populações e dos desterrados, grandes massas de pessoas constantemente se tornam supérfluas se continuarmos a pensar em nosso mundo em termos utilitários. Os acontecimentos políticos, sociais e econômicos de toda parte conspiram silenciosamente com os instrumentos totalitários inventados para tornar os homens supérfluos. [...] As soluções totalitárias podem muito bem sobreviver à queda dos regimes totalitários sob a forma de forte tentação que surgirá sempre que pareça impossível aliviar a miséria política, social ou econômica de um modo digno do homem.
\end{abstract}

Diversos fatores contribuem ainda hoje para tornar supérfluo o ser humano, como o crescimento do desemprego. Outro fator alarmante é a crise dos refugiados na Europa é alarmante por ser a maior em muitos anos. Dados apontam que o número de refugiados se iguala aos dos anos posteriores à Segunda Guerra Mundial. Diante do grande número de pessoas consideradas supérfluas aos governos dos países desenvolvidos, pode-se ter a tentação de usar a solução totalitária, mesmo que com novo formato, ante a impossibilidade de se resolver tal problema.

Ainda que superada pela própria autora em obras posteriores, as análises arendtianas da expressão radical do mal nos mostram a que ponto a maldade humana pode chegar. Não se pode considerar o mal radical como problema do passado, já superado. É preciso lembrar que todos os horrores provocados pelas guerras mundiais aconteceram justamente numa época em que se achava que o progresso da humanidade havia chegado a patamares tão altos que toda forma de mal seria suprimida.

Entretanto ao se perceberem tais elementos desfavoráveis à raça humana ainda hoje, não se deve desanimar. Hannah Arendt, em outras publicações, mostrou que uma das mais importantes e belas capacidades humanas é a liberdade, a capacidade de começar algo novo. Restaurando-se o espaço público, em que os problemas da humanidade sejam discutidos, iniciando ações políticas que visam à restauração da dignidade humana e da própria política, uma nova maneira de as pessoas estabelecerem relações entre si é possível. 


\section{Referências}

ARENDT, Hannah. Origens do totalitarismo: antissemitismo, imperialismo, totalitarismo. Tradução Roberto Raposo. 4. ed. São Paulo: Companhia das Letras, 2012. 832 p.

CORREIA, Adriano. Arendt e Kant: banalidade do mal e mal radical. Argumentos, Fortaleza, ano 5, n. 9, p. 63 - 78, jan./jun. 2013. Disponível em:

<https://www.academia.edu/9799065/Arendt_e_Kant_banalidade_do_mal_e_mal_radical >. Acesso em: 03 out. 2015.

DUARTE, André. O pensamento à sombra da ruptura: política e filosofia em Hannah Arendt. São Paulo: Paz e Terra, 2000. 396 p.

LAFER, Celso. A reconstrução dos direitos humanos: um diálogo com o pensamento de Hannah Arendt. São Paulo: Companhia das Letras, 1988. 410 p.

SOUKI, Nádia. Hannah Arendt e a banalidade do mal. Belo Horizonte: Ed. UFMG, 1998. $156 \mathrm{p}$. 